\title{
Prospects of Using the Augmented Reality for Training Foreign Students at the Preparatory Departments of Universities in Ukraine
}

\author{
Natalya O. Zinonos ${ }^{1 \text { [0000-0003-2159-1295], Elena V. Vihrova [0000-0003-3046-0801] }}$ \\ and Andrey V. Pikilnyak ${ }^{1[0000-0003-0898-4756]}$ \\ ${ }^{1}$ State Institution of Higher Education "Kryvyi Rih National University" \\ 11, Vitali Matusevich St., Kryvyi Rih, 50027, Ukraine \\ zinonosei.ua, pikilnyak@gmail.com \\ ${ }^{2}$ Kryvyi Rih State Pedagogical University, 54, Gagarina Ave., Kryvyi Rih, 50086, Ukraine \\ elvihrova65egmail.com
}

\begin{abstract}
The purpose of the study is to highlight the potential and the prospects of using the augmented reality in the mathematical education for foreign students at the preparatory departments of universities. Objectives of the study: to determine the peculiarities of the virtualization of the training of foreign students at the preparatory departments of universities, as well as the possibilities of using the technology of complementary reality in the teaching of mathematics. Object of research: a virtually oriented educational environment of foreign students at the preparatory departments of universities. Subject of research: virtualization of learning with the augmented reality of mathematical education of foreign students at the preparatory departments of universities. Used research methods: theoretical - analysis of scientific and methodological literature; empirical-study, observation of the educational process. Results of the research: on the basis of the analysis of scientific publications, the notion of virtualization of education and the virtually oriented educational environment of foreign students at the preparatory departments of higher educational institutions is described. The main conclusions and recommendations: 1) the article outlines the possibilities and prospects of using the augmented reality in the mathematical education for foreign students at the preparatory departments of universities; 2) the considering the various targets of mobile applications, which are used in solving mathematical problems, as well as analysis of the characteristics of various practical achievements of using the augmented reality in the mathematical preparation for foreign students at the preparatory departments of universities, it is planned to devote a separate work.
\end{abstract}

Keywords: foreign students, augmented reality, a virtually oriented learning environment, mathematics training. 


\section{$1 \quad$ Problem statement}

The training of foreign students at the preparatory departments of national universities is preceded by a diligent, purposeful work of both students and future teachers, aimed at successful adaptation of students to the new environment of the country's future education [11]. Studying abroad is like turning over a new leaf in an unknown world. However, conditions of entry vary significantly between individual countries and universities. It is entirely natural that a young person who is planning to graduate in another country will try to learn as much as possible about the conditions of residence and education in that country. The following forms and methods are used in preparing for study visit:

- communication with those who have been in the country for some time or with a tourist trip, or have been trained before;

- viewing of printed sources, cinema, video materials, which give an idea of the country of the future education;

- remote communication through forums and social networks with residents of this country and selected institution of future education;

- acquaintance with the Internet-representations of a higher education institution in which the person is planning to study;

- initial mastery of the language and backgrounds of the culture of the country of future education.

Studying at the preparatory departments for foreign students of the national universities, especially at the initial stage, have a number of characteristics, among which:

- immersion in a neutral or unfriendly language and social environment;

- fundamental differences in the organization of the learning process in their native country and Ukraine;

- problems when transferring previous experience of educational activity into a new educational environment;

- significant differences in the partial teaching methods.

\section{Discussion and results}

All of this influences on quality of teaching foreign students at the preparatory departments of national universities and needs to find ways to increase the level of preliminary students' preparedness to study in a new environment. The use of modern information technology opens up new opportunities for raising this level. To the means aimed at increasing the level of preliminary preparedness of foreign students to study, which should provide a higher education institution can be attributed:

- two (many) language of the Internet representation (site) of the university; 
- the saturation of short and medium length of the video, such as "virtual tour" (level institution of higher education, teacher, audience, dean's office) in the languages of potential entrants (in Ukrainian with customized subtitles);

- distance support organization of future applicants in the study of the basics of the Ukrainian language with the students-volunteer of the Faculty of Foreign Languages, International Department et al.;

- availability of bilingual courses in educational discipline (mathematics, physics, etc.) on the site of the university (e.g., Moodle);

- development of simulators (linguistic, social-behavioral, educational).

Consequently, there is a need to supplement the educational environment of the institution of higher education with the means of information and communication technologies that extend it to a virtually oriented environment. Virtual excursions and virtual learning environment, multilingual reproduction of multimedia materials can be attributed to the means that it is expedient to use at the stage of preparation for coming to the country of future education of foreign students. These tools provide an opportunity to build a more adequate model of higher education in the country's future student education, which will help reduce the initial disadaptation level. The technology of the translation of oral speech (audio), or the reproduction of translated text; audio guides by geographical coordinates, or certain marks (orientation in the city, institution of higher education, treatment of notation, etc.) are means that will facilitate oral communication. Tools that help bridge the differences in the organization of the learning process - is the development and use of bilingual textbooks for establishing the relationship between the content of the concept and its interpretation in different languages; situational means of visibility used in a particular context (place, time, subject of class, etc.); dynamic computer models complementing traditional teaching materials.

For hundreds of years, young people have come abroad to learn new things and find direction in life. But now, with the help of technology, the way knowledge passes from teachers to their students is changing. Virtual environments are computer-simulated environments representing real or imaginary worlds. It is important to understand how valuable knowledge can be acquired within virtual environments, and how it can be transferred to real-world situations. We describe the possibility of using augmented reality in mathematics training of foreign students. It should be noted that information technologies enable the development of innovative tools for teaching mathematics both in the audience and beyond [9]. In recent years, we have seen a significant increase in the use of mobile devices as tools in education [2; 7]. It is better to analyze the application of these modern gadgets in reference to the usual pedagogical terms: educational process, learning content, forms and technologies.

The process of training is a purposeful, consistently organized interaction between the teacher and students, mediated by the content of activities, during which the tasks of education, education and general development of students are solved. If to improve the content of the educational material the most important tasks is its systematization, updating and problematization, for the development of forms - activation of training, for the method - individualization and automation, then for the improvement of pedagogical means the most important today is recognized visualization. 
Based on the research by Iryna V. Salnyk, we will define a virtually oriented learning environment as an environment in which information and communication technologies are combined with traditional teaching technologies, complementing and expanding them [6]. Virtual environment tools (the most popular is Moodle [5]) are implemented parallel with traditional lectures and workshops. According to the work of Valerii Yu. Bykov into the structure of a virtually-oriented learning environment included: subjects of training, content of training, means of training and communication tools [1]. The virtuality of a virtually-oriented learning environment is achieved with:

1. the possibility of realization of educational activity of subjects of studying by lecturers and non-auditors, directly and indirectly by means of training;

2. the ability to present the content of learning in different modalities, using channels of educational communication;

3. the use of teaching aids aimed at the implementation of the content of training and support of widespread educational communication;

4. the use of communication tools aimed at supplementing non-auditing educational activities to the level of the auditorium.

The ways of supplementing the traditional learning environment with ICT tools are:

1. inclusion in the educational process of fragments of activities that require ICT tools (work with computer models, computer learning environments, communication facilities, etc.);

2. involvement in the classroom process of persons who cannot be present in the audience personally (persons with special needs, teachers with a low level of geographical mobility, etc.);

3. the use of ICT tools, complementary to traditional teaching tools (means of complemented reality).

If in the complement of the traditional learning environment the first direction is the leading means of ICT, then this environment is called a computer-based learning environment (according to Myroslav I. Zhaldak [10]), if the second one is a mobile-oriented learning environment (according to Mariia A. Kyslova) [3], if the third one is a virtually oriented educational the medium of complemented reality.

Effective functioning of the virtual environment at the preparatory department for foreign citizens of universities is provided through the activities of the teacher and students who create mutual relationships with each other and with other elements, coexist with the traditional learning environment, expands its capabilities and creates conditions for the implementation of new technologies, forms and methods of teaching mathematics.

The technology of augmented reality is becoming increasingly popular every day and is increasingly used in various fields. The term Augmented reality was coined as an expression in 1990 by Thomas Caudell [4] at Boeing, but the idea goes back much further than that. Today, technologies of the augmented reality allow through the camera of a mobile device to read from the surrounding objects additional information - to watch videos, three-dimensional objects, etc. Increasing processes of the creation and 
implementation of new technologies stimulate constant change of the education system. Now it is not necessary to carry books with you, it is enough to download special programs in the smartphone and it can be readily available in an easy and accessible form. In order to successfully use the technologies of the augmented reality technology, it is necessary to prepare foreign students alike - to accustom them to the use of the service, to capture the interesting possibilities. By combining books or print documents using augmented reality technology, teachers can give foreign students access to digital content and deepen their learning in 3D space. In addition, teachers can teach foreign students individually and train distantly.

The peculiarity of teaching foreign citizens at the preparatory department for universities is that, in a rather short period of time, students must learn not only a sufficient amount of theoretical knowledge and practical skills in mathematics [8], but also create their own lexical base in a non-native language of instruction. Therefore, it is advisable to use both English and non-English mobile applications in order for foreign students to have a mathematical apparatus in the language of training. For example, use the Math 42 application. This is an indispensable mathematical program, both for the student. In real time, this application not only solves the equation that is introduced into it, but also distributes the progress of the decision, clearly explaining the solution to the example. In addition, Math 42 offers several solutions at once, helping to choose the most optimal and understandable option for the student. Also, the program has a training section, where the student can learn the material that has been studied before.

The Math 42 application can help you cope with the following mathematical operations: simplification; multiplication, reduction and addition (including fractions); division of polynomials; solving linear and square equations etc. The graphics of the program are quite nice, and a simple interface makes the program easy to use.

\section{Conclusion}

By using students' and teachers' feedback, and the comparison with a traditional class, we hope using augmented reality will help foreign students to solve their problems in mathematical preparation. During the educational process along with the mastery of systemic basic knowledge and key competencies form the need for mastering mathematical vocabulary as a means of communication, knowledge, self-realization and didactic adaptation of foreign students. Finally, the prospects of using augmented reality technologies for communicative-oriented learning of foreign students are in its multipurpose and multifunctional orientation, as well as its integration into a holistic educational process.

\section{References}

1. Bykov, V., Shyshkina, M.: Emerging technologies for personnel training for IT industry in Ukraine. In: Proceedings of ICL2014 - 2014 International Conference on Interactive Collaborative Learning, Dubai, 03-06 December 2014, pp. 945-949. IEEE, Red Hook (2014). doi:10.1109/ICL.2014.7017903 
2. Horshkova, H.A., Vikhrova, O.V.: Zastosuvannia resursu «Plickers» dlia otrymannia zvorotnoho zviazku na lektsiiakh z vyshchoi matematyky (Application of the resource "Plickers" for feedback on lectures on higher mathematics). New computer technology. 14, 110-111 (2016)

3. Kyslova, M.A., Semerikov, S.O., Slovak, K.I.: Rozvytok mobilnoho navchalnoho seredovyshcha yak problema teorii i metodyky vykorystannia informatsiino-komunikatsiinykh tekhnolohii v osviti (Development of mobile learning environment as a problem of the theory and methods of use of information and communication technologies in education). Information Technologies and Learning Tools. 42(4), 1-19 (2014)

4. Modlo, E.O., Echkalo, Yu.V., Semerikov, S.O., Tkachuk, V.V.: Vykorystannia tekhnolohii dopovnenoi realnosti u mobilno oriientovanomu seredovyshchi navchannia VNZ (Using technology of augmented reality in a mobile-based learning environment of the higher educational institution). Naukovi zapysky, Seriia: Problemy metodyky fizyko-matematychnoi i tekhnolohichnoi osvity. 11(1), 93-100 (2017)

5. Nechypurenko, P.P., Semerikov, S.O.: VlabEmbed - the New Plugin Moodle for the Chemistry Education. In: Ermolayev, V., Bassiliades, N., Fill, H.-G., Yakovyna, V., Mayr, H.C., Kharchenko, V., Peschanenko, V., Shyshkina, M., Nikitchenko, M., Spivakovsky, A. (eds.) ICT in Education, Research and Industrial Applications. Integration, Harmonization and Knowledge Transfer 2017, 13th International Conference on ICT in Education, Research and Industrial Applications. Integration, Harmonization and Knowledge Transfer (ICTERI, 2017), Kyiv, Ukraine, 15-18 May 2017. CEUR Workshop Proceedings (CEUR-WS.org), vol. 1844, pp. 319-326 (2017)

6. Salnyk, I.V.: Psykholoho-pedahohichni osnovy virtualizatsii protsesu navchannia fizyky v starshii shkoli (Psychological and pedagogical bases of the virtualization teaching physics in senior school). Pedagogical process: theory and practice. 1, 92-99 (2014)

7. Semerikov, S.O., Striuk, M.I., Moiseienko, N.V.: Mobilne navchannia: istoryko-tekhnolohichnyi vymir (Mobile learning: historical and technological dimension). In: Konoval, O.A. (ed.) Teoriia i praktyka orhanizatsii samostiinoi roboty studentiv vyshchykh navchalnykh zakladiv (Theory and practice of organization of independent work of students of higher educational institutions), pp. 188-242. Knyzhkove vydavnytstvo Kyreievskoho, Kryvyi Rih (2012)

8. Vihrova, O., Zinonos, N.: Otsiniuvannia adaptyvnykh staniv studentiv-inozemtsiv na pochatku vyvchennia pryrodnycho-matematychnykh dystsyplin (The evaluation of foreign students' adaptation at the beginning of learning science and mathematics). Visnyk Cherkaskoho universytetu: Pedahohichni nauky. 7, 51-56 (2016)

9. Vikhrova, O.V., Zynonos, N.O.: Metodychni osoblyvosti navchannia matematyky inshomovnykh studentiv na pidhotovchykh fakultetakh vitchyznianykh vuziv (Methodical specifics of teaching mathematics to foreign students at the preparation departments of Ukrainian universities). Aktualni pytannia pryrodnycho-matematychnoi osvity. 1, 5-8 (2013)

10. Zhaldak, M.I.: Pedahohichnyi potentsial kompiuterno-oriientovanykh system navchannia matematyky (Pedagogical potential of computer-oriented systems of teaching mathematics). Kompiuterno-oriientovani systemy navchannia. 7, 3-16 (2003)

11. Zinonos, N.O.: Vykorystannia modeli adaptatsii studentiv dlia navchannia inozemnykh studentiv u VNZ Ukrainy (Using of the students' adaptation model for teaching foreign students). New computer technology. 15, 42-46 (2017) 